\title{
Prophet Muhammad (pbuh) Practices to Establish a Pluralistic Society: Study of Madīnah Charter in Contemporary Global Context
}

\author{
Riaz Ahmad Saeed, Sumayyah Rafique \\ The National University of Modern Languages (NUML), Islamabad, Pakistan \\ Naseem Akhter \\ Shaheed Benazir Bhutto Women University, Peshawar, Pakistan \\ Zahid Lateef \\ University of Engineering \& Technology, Lahore, Pakistan \\ Abu Bakar Bhutta \\ National University of Modern Languages( NUML), Islamabad, Pakistan \\ Hafiz Muhammad Naeem \\ Governmnet College University, Lahore, Pakistan
}

\begin{abstract}
This study explores the practices of the Holy Prophet Muhammad aلd suluale establish a peaceful and diverse society with special reference to Methāq-e-Madīnah and its significance and application in contemporary socio-political context. Theoretically, the effort and dream to establish a peaceful and diverse society have been a matter of concern for the humanity from the ancient times. But it has become the most significant and burning issue of the contemporary global scenario. Ultimately, the human intellectual and physical development is based upon peace and peaceful coexistence. Therefore, a number of religious and socio-political scholars have been tried to establish

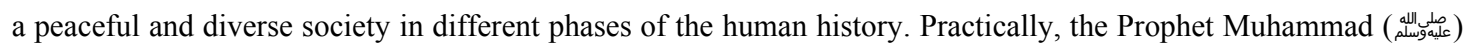
has made a unique and distinct contribution towards developing a peaceful and diverse society for 1,400 years ago, though he led or had been the part of multiethnic society of different faiths in the state of Madinnah. In order to establish a peaceful and pleasant relationship between Muslims and other communities of Madīnah, an agreement was signed which was titled Methāq-e-Madīnah. The Charter of Madīnah contained certain principles and regulations that are mandatory for a peaceful living in a diverse state or society. This charter is an excellent model for peace, prosperity, religious freedom, and human rights in the human history. According to this charter, all
\end{abstract}

Riaz Ahmad Saeed, Dr., Lecturer, Department of Islamic Studies, The National University of Modern Languages (NUML). Sumayyah Rafique, Dr., Assistant Professor, Department of Islamic Studies, The National University of Modern Languages (NUML).

Naseem Akhter, Dr., Assistant Professor, Department of Islamic Studies, Shaheed Benazir Bhutto Women University. Zahid Lateef, Dr., Assistant Professor, Department of Islamic Studies, University of Engineering \& Technology.

Abu Bakar Bhutta, Dr., Assistant. Professor, Department of Arabic Language \& Literature , National University of Modern Languages( NUML).

Hafiz Muhammad Naeem, Dr., Chairman of Department of Islamic Studies, Governmnet College University. 
groups were free to exercise their religious beliefs and social and economic interests. According to this agreement, Madīnah was declared a federal capital of the state. This agreement had provided equal rights, religious autonomy, and socio-cultural freedom to all other groups of the Madinnah (Jews, Christians, and polytheists). Therefore, it is perceived that the Charter of Madinah may become a preamble for peaceful coexistence in this multicultural and multipath world of the contemporary era. In this study, analytical research methodology has been adopted with qualitative approach.

Keywords: prophet approach, peaceful and diverse society, Methāq-e-Madīnah, modern era

\section{Introduction}

Peaceful and diverse society has been the most vibrant issue for humanity from the very first day of the history. Especially, it has become the most significant and most throbbing problem in modern socio-political context. Therefore, the experts of every religion and community have assumed the fact that the material and intellectual development of humanity are based on peaceful and diverse coexistence. The messengers of God, different leaders, and experts have been tried their best to make peaceful coexistence in a diverse society during different phases of the human history. Definitely, every individual has its own vision and significance for that issue, but a persuasive effort has been made by the Holy Prophet Hazrat Muhammad ( dynamic struggle for establishing peace, but a divine model character that influenced human being in a short period of human history.

It is a historic fact the Holy Prophet Muhammad (allughale) is the messenger of peace and mercy for the welfare of society until the Day of Judgment. His ( (allugatce divine message of peace and mercy includes not only the Muslims community but also the whole humanity around the Globe, superior to sects, faiths, and cults. Therefore, God declared him a prophet of peace and mercy to all human being in his divine book: "We sent thee not (The messenger of Allah), but as a Mercy for all creatures" (Al-Quran, 2004, pp. 21, 107).


way, "A perfect Muslim is one from whose tongue and hands, mankind is safe" (Qushairī, 2007, p. 1). Doubtlessly, it is a universal sacred message of peace for a diverse society without any discernment of religion,

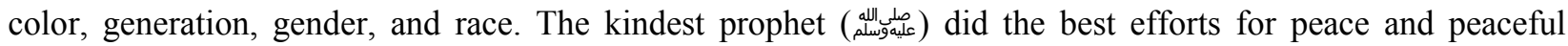
coexistence in this multiethnic and diversified society. Therefore, Muslim scholars and some non-Muslims scholars highly recognize the divine efforts of socio-religious, sociological contribution made by the Holy Prophet Muhammad aلw allese. It is not a folk tale but a patent fact of the human history. A reputed Muslim scholar Prof. Dr. Fauzī Ahmad Abdul Hamid articulates: "History has neither witnessed nor will ever witness again another human figure whose presence, thought, action, inaction and eventual demise exerted such a profound impact on humanity as did the Holy Prophet Muhammad (aلdugatce)" (Hamid, 2009, pp. 1-35). Even the impartial opponents of Islam and prophet of Islam allwalle also accept this irrefutable truth. One of the most dominant voices of them is a well-known Christian Scholar Michal H. Hart. He admires the prophet allugate in his book The Hundred as top story. According to his beautiful worlds:

My selection of Muhammad to front the list of the world's most high-ranking persons may astonish some readers and may be queried by others, but he was the only man in the human history that was extremely victorious on both the religious and secular (socio-political) levels. (Hart, 1992, p. 3) 
Moreover, the mercy, justice, and cooperation of the prophet allughe have been the most essential part in his routine life even before the announcement of his prophet-hood. The whole life of the prophet allugate passed to fight for rights, mercy, and justice in a violent and discriminating society. According to the Qurānic who discoursed that another important duty of the prophet aلlughe is is to make free the human being from so called religious, political, and social burdens and slaveries. Actually, it is a great blessing on humanity of the almighty through the kind prophet allugale. Therefore, The Holy Quran considers it good news and divine effort for the human beings:

He commands them what is just and forbids them what is evil; he allows them as lawful what is good and prohibits them from what is bad; He releases them from their heavy burdens and from the yokes that are upon them. (Al-Quran, 2004, pp. 7, 157)

The prophet ealle described an example to elaborate his genius character in this sense:

Example of mine and yours is like of a man who light the fire and bugs and moths started to drop in it and he would be trying to get them out, and I am going to grasp you reverse from flames, but you are falling from my hand. (Qushairī, 2007, p. 64)

Accordingly, in this study, the academic efforts are made to highlight the immense role of the holy

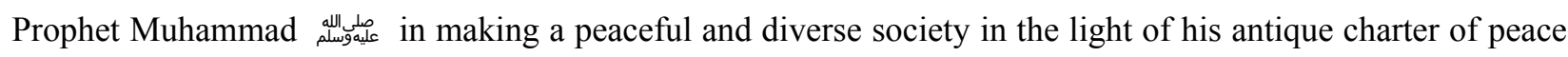
and prosperity known as "Methāq-e-Madīnah" in human history.

\section{Role of Methāq-e-Madīnah in Promotion of Peaceful and Diverse Society}

The first and last objective of the Charter of Madīnah (Methāq-e-Madīnah) was to promote peaceful and tolerant environment in the city, State of Madīnah. So, for that purpose, it seems better; first of all, we try to know the importance of this historical peace charter in promotion of peace and diversity. Doubtlessly, it is a trustworthy historical socio-political and socio-economic document and every reasonable scholar from Muslims and even non-Muslims mention it in his worthy writings. Numerous Muslim scholars give much weightage to it and launch research about its validity, position, and influences. The most imminent and valuable research work about this historical document is, of course, of a reputed Muslim scholar of Dr. Muhammad Hamīdullah. He stated about the legitimacy of this antique document in this way:

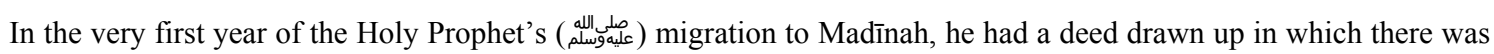
a detailed discussion of the prerogatives and obligations of the ruler as well as of other immediate requirements. Fortunately, the whole of this document, word for word, has been reproduced by Ibn-e-Ishāq and Abu Ubaīd in their respective books. (at https://ia800409.us.archive.org/11/items/)

Another well-known contemporary seerah writer Dr. Zia al-Umarī also speaks out about its legality in his significant book "As-Seerah An-Nabawiyyāh As-Sahéhah". He specified about the validity of the Methāq-e-Madīnah after studying the various related chains of narrations of this important document. He articulated, "When those narrations are considered as a group, they strengthen one another to the degree that

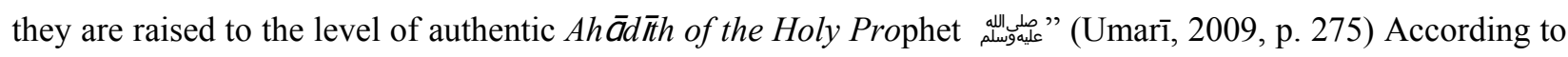
the historians, this document has 53 articles, sections, or clauses, and two parts: One part is related to the Muslims affairs (Ansār and Muhājrīn) while second part of the charter is relevant to the non-Muslims minorities affairs (Jews, Christians, and polytheists). Here, Dr. Muhammad Hamīdullah expressed about details of this historic document, 
This document contains 53 sentences, or, to use legal terminology, Articles; and is an invaluable example of the legal language and the manner of document-writing of the time. The importance of it has been felt by the European Christians even more than by the Muslim historians. (Hamīdullah, 1987, p. 15)

Therefore, it can be perceived that the Peace Charter of Madīnah (Methāq-e-Madīnah) has equal socio-political and intellectual importance for Muslim and non-Muslim scholars both. Every reliable Muslim and non-Muslim write and scholar gives place to this important document in his writings and research on the holy prophet

\section{Socio-political Status of the Elements of the Society (Stakeholders)}

Though this charter gives Muslims a kind of rule and authority over others political and religious elements of Madīnah, it also gives them equal rights of citizenship, social, and religious liberty and other basic rights equally. As we have studied before that there were three major parties (stake holders) in the state of Madinnah, Jews, Muslims, and polytheists, including hypocrites (Munāfqīn). Here, Prof. Siddique Qureshi rightly stated, "Madīnah was the pluralistic and diverse society of different faiths and religions; Muslims, Jews and Polytheists of Aw's and Khizraj" (Qurésh̄, 1998, p. 147). These three groups were equal partner in rights, freedom, duties, liberties, and responsibilities. The Article No. 1 and 26 of the charter tell its details:

Jews and Muslims are equal political partners: (26) the Jews shall be considered as one political community (Ummat) along with the believers for the Jews their religion, and for the Muslims theirs, be one client or patron. He, however, who is guilty of oppression or breach of the treaty, shall suffer the resultant trouble as also his family, but no one besides. (Hmaīdulah, 1968, p. 15)

It means that the Charter of Madinnah basically defines the roles and regulations, power and authority, and rights and responsibilities. According to the most cherished views of Prof. Dr. Ali Muhammad Al-Sullābī:

The constitution clearly expressed that the Jewish inhabitants of Madinah were citizen of the Muslim State. They have the right to help and they will not be wronged. As for long a different religious affiliation was not a reason to prevent one from becoming a citizen. (Al-Sullābī, 2008, p. 203)

It is clearly stated that, according to this historical Charter of Madīnah, any religious or ethnic identities are not prohibited in citizenship of the state. It means any non-Muslim minority or ethnic group can become citizen an Islamic state and avail all kinds of rights and liberties in an ideological Islamic state, if he/she fulfills other requirements for loyalty and commit with state.

\section{Mutual Cooperation on Socio-political Level}

Mutual cooperation between socio-political partners in peace and war and other social and economic issue is another most dominant feature of this historical charter. Numerous clauses of the charter are witnesses of this fact. Article No. 25 of the charters elaborates it as, "The Jews shall share with the believers the expenses of war so long as they fight in conjunction with the believers" (Hmaīdulah, 1968, p. 25). In addition, the Article No. 40 tells,

If any one fights against the people of this code, their i.e., of the Jews and Muslims) mutual help shall come into operation, and there shall be friendly counsel and sincere behavior between them; and faithfulness and no breach of covenant. (Hmaīdulah, 1968, p. 40) 
Especially, the Article No. 44 expresses it as, "and they (i.e., Jews and Muslims) shall have each other's help in the event of any one invading Madinah" (Hamīdullah, 1987, p. 44). Moreover, the Article No. 47 declares the war and peace of the Jews and Muslims will be considered similar:

And if they (i.e., the Jews) are invited to any peace, they also shall offer peace and shall be a party to it; and if they invite the believers to some such affairs, it shall be their duty as well to reciprocate the dealings, excepting any one makes a religious war. (Hamīdullah, 1987, p. 47)

Eventually, this peace charter allows the mutual sharing and cooperation in state, and the socio-political and socio-economic issues between Muslims and non-Muslims. Therefore, Muslim can help non-Muslims, and non-Muslims should help out the Muslims in collectives' issues of the society and state.

\section{Eradication of Crimes and Social Injustice}

Furthermore, this charter offers a strong foundation to eliminate the social crimes and discrimination. It is not only for Muslims adherents, but every political partner was bounded to do it. Therefore, it promotes joint approach in elimination of social misconducts and prejudice, and does not spare any person or nearest relations even the son of a father in implementation of this law. The Article No. 13 tells it in particulars,

And the hands of pious believers shall be raised against every such person as rises in rebellion or attempts to acquire anything by force or is guilty of any sin or excess or attempts to spread mischief among the believers; their hands shall raise all together against such a person, even if he be a son to any one of them. (Hamīdullah, 1987, p. 13)

This legal document provides most care to peace, prosperity, and diverse living; the last paragraph and clause of the charter is also related to the social prosperity and peaceful mutual coexistence. As we study in the Article No. 50 of the Constitution:

And this prescript shall not be of any avail to any oppressor or breaker of covenant. And one shall have security, whether one goes out to a campaign or remains in Madīnah, or else it will be an oppression and breach of covenant. And God is the Protector of him, who performs the obligations with faithfulness and care, as also His Messenger Muhammad

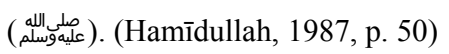

It is like daylight that the Charter of Madīnah has more concerns and focuses towards the establishment of peace, diversity, and prosperity in the state and society. For that purpose, Islam gives hand towards non-Muslim minorities for a peaceful and diverse living in a Muslim majority state and society. It is an understood realty; peace and prosperity are not possible without cooperation of all political, social, and religious elements of the state and society. Therefore, a pluralistic society is necessary for peaceful coexistence and smooth development. Furthermore, it can be said if a state or society has a credible joint system to eradicate the social crimes and unfairness then how misconducts can exist in the society.

\section{Social Harmony, Religious Liberty, and Fundamental Rights}

Another most important impact and impression of Methāq-e-Madīnah is the provision of interfaith harmony, civil liberties, and fundamental rights to adherents of the state. For that persistence, Islam endorses interfaith harmony, tolerance, and dialogue since its begging for the establishment of peaceful and diverse society. Therefore, the Charter of Madīnah grants all kinds of liberties, fundamental rights, and harmony to the signatories of this peace pact. Moreover, for open minded, diverse, and pluralistic society, Islam initiates interfaith and intercultural dialogue between religions and communities. One of the most vital primary sources 
of the Islamic thought, The Holy Quran commands to Muslim believers to initiate dialogue among faiths, thoughts, and civilizations for the sake of mutual understanding, peace, and stability. Almighty Allah recommends dialogue with the People of the Book (Ahl al-kitāb) also with other faiths and communities in The Holy Quran: "Say (O Prophet (c) Co people of the Scripture; Come to a word that is just between us and you, that we worship none but Allah" (Al-Quran, 2004, pp. 3, 64).

To support the spirit of interreligious dialogue on the behalf of this verse of The Holy Quran, a renowned Muslim scholar Mușțafā Qāsim comments,

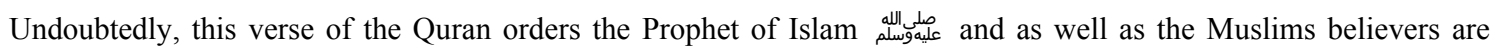
recommended to institute relations with the People of the Book (Ahl al-Kitäb) and to connect around common issues. In a manner, it illustrates a basic structure for dialogue. (Qāsim \& Krucān, 2012, p. 23)

The Charter of Madīnah (Mīthāq-e-Madīnah) is a social contract between different communities and provides all kinds of religious and social rights without racial, social, and religious bondage. Here, Prof. Dr. Muhammad 'Ammārah writes:

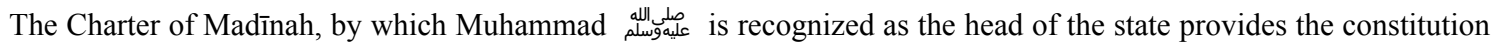
of the city-state of Madīnah, is characterized by pluralism and liberty, relatively different from the nation-states which are fabricated around an ethnic and linguistic society. It arranges the standard of communal liability of the groups. ('Ammārah, 1996, p. 132)

It is also a point of distinction that Islam promotes freedom of religion to the human being due to its respect and dignity. The Holy Quran proclaims: "Let there be no compulsion in religion: Truth stands out clear from Error: whoever rejects evil and believes in Allah hath grasped the most trustworthy hand-hold that never breaks" (Al-Quran, 2004, pp. 2, 256).

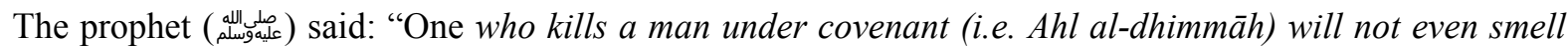
the fragrance of Paradise" (Al-Quran, 2004, pp. 9, 45). The Charter of Madīnah grants all kinds of social, religious, and political fundamental human rights and civil liberties. Numerous clauses of the charter are observer of it. The Article No. 25 of the Constitution elaborates it most likely:

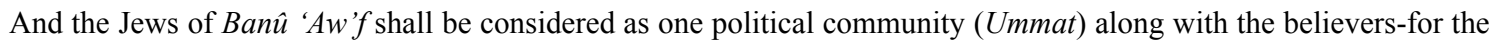
Jews their religion, and for the Muslims theirs, be one client or patron. He, however, who is guilty of oppression or breach of treaty, shall suffer the resultant trouble as also his family, but no one besides. (Hamīdullah, 1987, p. 25)

Besides, this charter also tells that the mutual connection of Muslims and Jews will be in good way instead of interfaith conflicts and clashes. Means Muslim will not interfere in Jews religion and Jews will not interfere in Muslim religious affairs. According to the Article No. 45 of the Constitution of Madīnah:

And if they (i.e., the Jews) are invited to any peace, they also shall offer peace and shall be a party to it; and if they invite the believers to some such affairs, it shall be their (Muslims) duty as well to reciprocate the dealings, excepting that any one makes a religious war. (Hamīdullah, 1987, p. 45)

To explain this clause of the charter, Prof. Dr. Ali Muhammad As-Sallābī writes, "The constitution declared the freedom and rights of all citizens, including the Jewish inhabitants of Madinnah who lived under the banner of the Islamic nation" (Al-Sullābī, 2008, p. 499). Therefore, it can be said with certainty and clarity that this Charter of Madīnah provides all kinds of, religious freedom, civil liberties, and fundamental rights for 1,400 years ago without any movement, struggle, and protest, which the Universal Declaration of Human 
Rights (UDHR) announced in 1948 after a long struggle and protest in the Western world. It is also perceived that all prevailing fundamental human rights are civil liberties, including freedom of religion that is imitation of

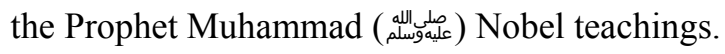

\section{Safety of Madīnah From External Invasions}

External peace is also most important concern of the Charter of Madinnah. A good deal of historians and seerah writers, for essential needs of this Constitution, was due to internal and external security issues of the State of Madīnah. Here, Dr. Muhammad Hamīdullah commented,

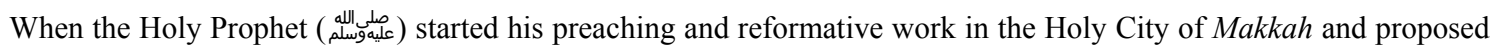
a change in the beliefs and practices existing for generations, he first surprised his countrymen, then he was hated and, in the end, he encountered their opposition and hostility. (Hamīdullah, 1987, p. 68)

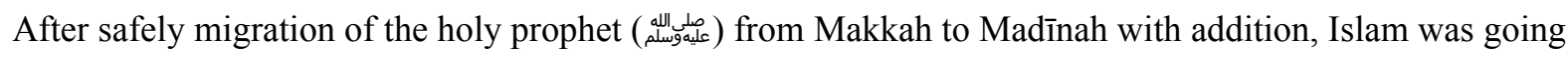
to establish and develop day by day in Madīnah, then the Quraish-e-Makkah sensed danger it for them. Thus,

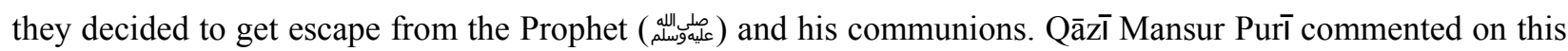
situation;

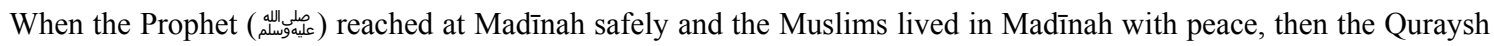
of Makkah started the conspiracies against Muslims. Even they demanded from the inhabitant of Madinnah to exit the Muslims from Madīnah. (Mansūpurī, 2007, pp. 1/97)

Therefore, it was obligatory for all of the Muslims and as well as other citizen of the state to secure

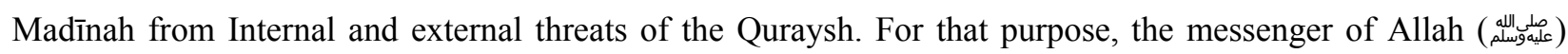
decided to unite all the communities of Madinnah for the internal and external defense of Madinnah under the canopy of the Charter of Madīnah. Here, Professor Siddīque Qureshi rightly comments: "The central point of the agreement was war and Peace issues. It was decided that the war and peace would be made collectively not individually. The war service considered mandatory for everyone (from Muslims and Jews)" (Quréshī, 1998, p. 181). Therefore, it is perceived that most of the clauses of the Charter of Madīnah deal with mutual cooperation, war, and peace issues. Article No. 2 and 3 of the charter also depicts: "The Muslims shall constitute a separate political unit (Ummat) as distinguished from all the people (of the world). They shall be for their own ward; and shall pay their fines (Dīyyat, blood money, and ransom), etc.” (Hamīdullah, 1987, pp. 2-3).

It is perceived many times that the most vigorous objective of the Charter of Madinnah was the defense of Medina from external and internal threats and invasions. Therefore, for this key objective to help out the Quraysh in any means was considered a war crime. Here, Article No. 43 of the Constitution tells: "The Quraysh shall be given no protection nor shall they who help them. And they (i.e., Jews and Muslims) shall have each other's help in the event of any one invading Yathrib (Madīnah)" (Hamīdullah, 1987, pp. 43-44). Prof. Dr. Nisār Ahmad rightly commented on this clause of charter:

This was declared in this constitution that nobody will help and protect the Quraysh openly and the whole of Madinnah

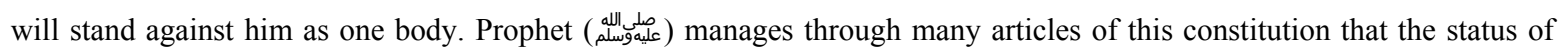
Quraysh becomes a unanimous enemy of Madīnah. (Ahmad, 1983, p. 5:108)

Here, we cannot ignore this fact that the strategy of war and peace play vital rule in the defense and

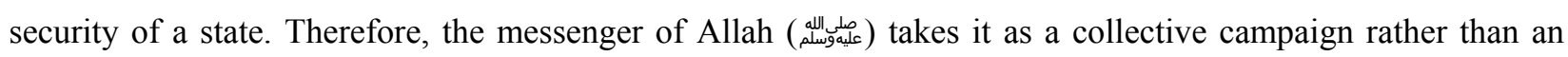


individual duty, then the help and protection of external warriors can be restricted. The Article No. 45 goes to this one,

And if they (the Jews) are invited to any peace, they also shall offer peace and shall be a party to it; and if they invite the believers to some such affairs, it shall be their duty as well to reciprocate the dealings, excepting that anyone makes a religious war. (Hamīdullah, 1987, p. 45)

If we keenly observe the war strategy of the Prophet Muhammad alluballe, then we reach to the conclusion

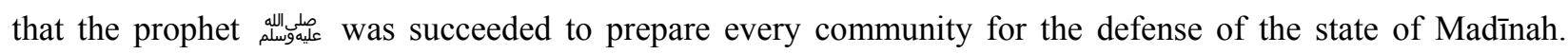
Especially, the last clause of the charter declares peace for every friend and war for every enemy. It was the

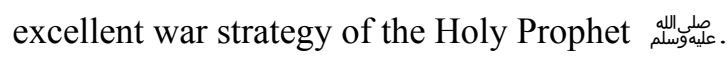

\section{Ensured Internal Peace of the City State of Madīnah}

The most important need of the agreement of the Madinnah was the internal security of Madinnah. It is an interesting fact that the intertribal battles of Aw's and Khizrij with conspiracies of the Jews were made them tired and deteriorate. They wanted peace ultimately for social and economic growth, for political and social stability and integrity of the society. Therefore, Mr. Naéem Siddīquī rightly commented:

The tribes of Aw's and Khizrij had a history of clashes and conflicts and the common public was also exhausted from conflict after conflict. Always some Arabs and some Jews were on a one side and some Arabs and some Jews were on another side. In this situation the wish of peace was there and they were searching a constructive leadership for peace and prosperity. (Naeem, 1998, p. 208)

It was a pleasant incident or good news for the people of Madinnah that in the meanwhile, the holy prophet (م) arrived at Madīnah and offered them a peace agreement. They said well come it even the Jews had no objection to this agreement.

Moreover, according to this peace treaty, all tribes and communities of Madinnah were the part of this charter and responsible of internal peace and security according to their responsibility and authority. The Article No. 3 of the constitution states, the Muslims were responsible of security in their areas of population:

The Muslims shall be (responsible) for their own ward; and shall pay their blood-money in mutual collaboration and shall secure the release of their own prisoners by paying their ransom from themselves, so that the mutual dealings between the believers are in accordance with the principles of goodness and justice. (Hamīdullah, 1987, p. 3)

Another Article No. 37 of the charter more clearly elaborates it,

The Jews shall bear the burden of their expenses and the Muslims theirs. And if any one fights against the people of this code, their i.e., of the Jews and Muslims) mutual help shall come into operation, and there shall be friendly counsel and sincere behavior between them; and faithfulness and no breach of covenant. (Hamīdullah, 1987, p. 37)

As well as for internal security of Madīnah every ally and its clients were responsible for peace of their areas. In addition, Madīnah was declared the Haram (A war free sacred place). Article No. 39 of the Constitution explains it in more details, "and the valley of Yathrib shall be a Haram (war free sacred place) for the people of this code" (Hamīdullah, 1987, p. 39). This clause of the Charter of Madīnah and some others also make ensure the internal security and external defense of the state of Madinnah with all inhabitants, allies, including Jewish minority. 
According to the humble opinion, the Peace Charter of Madinnah deals with all kind of defense and security affairs as well as fundamental rights, civil liberties, peaceful and diverse mutual coexistence, and interfaith relations in a very modest and humble way which is necessary for peace, prosperity, economic development, and justice of any states or societies even in the contemporary era. The strategy of the holy prophet aلd alugas was succeeded because he wanted to contract every citizen and community of Madīnah for its external and internal defense, public peace, and stability. Consequently, it can be observed and stated undoubtedly that it was not just a political announcement or memorandum, but it was a divine charter of peace and prosperity which was implemented with its real spirit and wisdom through excellent moral and political will with help, assistance, and mutual consultation of all stake holders.

\section{Promotion of Peace and Diversity and Its Need in Modern Era}

One of the most important impact and role of this historical peace charter is the promotion of social and religious pluralism and diversity. It is an undeniable fact through primary sources of Islamic teachings that Islam promotes and like plural and diverse society, because it is impossible forever to establish a mono-cultural and mono-religious society. Therefore, the last book of Allah denies this myth.

If thy Lord had so willed, He could have made mankind one people: but they will not cease to dispute. Except those on whom thy Lord hath bestowed His Mercy: and for this did He create them: and the Word of thy Lord shall be fulfilled. (Al-Quran, 2004, pp. 11, 18-19)

This verse specially and many other verses of the Nobel Quran guide us towards social and religious diversity. It is a reality that social and religious diversity is a base of peace and prosperity of any society and state. Therefore, form the day first Muslim societies have been plural and diverse in terms religions and cultures. The primary sources of Islam do not advocate of monoculture and mono-religion society. Here, a leading Muslim scholar of twentieth century Prof. Dr. Khalid Alvi describes this truth in these words:

The Muslim societies have been plural and diverse from its foundation. (The society of the Prophet aلd aلم and state of Medina are the live examples of it). The non-Muslims are considered part of national narrative with their own separate identity. Special rules and regulations (Laws) are established to preserve their fundamental rights and civil liberties. (Alvi, Khalid, 2009, p. 587)

For that tenacity, Islam protects and provides them all kinds of religious and social rights and liberties. They have right to possess and act up on according to their religion and faith freely. Nobody can impose them to accept Islam. The book of Allah gives them freedom of religion and thought until they oppose the basic principles of Islam. Allah declares in the Nobel Quran: "Let there be no compulsion in religion: Truth stands out clear from Error: whoever rejects evil and believes in Allah hath grasped the most trustworthy hand-hold that never breaks" (Al-Quran, 2004, pp. 2, 256).

Additionally, the Charter of Madīnah gives the religious freedom to every partner of the agreement. According to this Peace Charter, religion has no compulsion as well as in religious issues every person free to act upon according his faith positively. An important clause (Article No. 25) of the Charter of Madīnah, deals with freedom of religion,

And the Jews shall be considered as one political community along with the believers-for the Jews their religion, and for the Muslims theirs, be one client or patron. He, however, who is guilty of oppression or breach of the treaty, shall suffer the resultant trouble as also his family, but no one besides. (Hamīdullah, 1987, p. 25) 
This clause of the charter gives religious freedom without any interference along with a mutual cooperation on state and society level. Here, a renowned seerah writer Muhammad Hussein Hackle stated, "The Prophet Muhammad allugate established a model state and society 1400 hundred years ago in which every community and religion of were of Madīnah were free to act upon according to his faith and creed" (Hackle, 1947, p. 227). In fact, it was Prophet's allughale wisdom and strategy of peaceful and dives society which made all communities of the state of Madinah safe and free.

Moreover, Muslim jurists and scholars have consensus up this issue that if a non-Muslims compel to embrace Islam, it is not valid and will not be accepted until he accepts Islam without any internal nod external pressure. Therefore, Islam not only dislikes the compulsion of religion, but also protects the right of freedom of faith and religion of every one. The renowned classical theologian, Ibn-e-Qudāmah Al-Muqaddasī writes:

This is not allowed to force a non-Muslim to embrace Islam. For example, if a disbeliever is compelled to believe in Islam, he will not be counted as a Muslim, except it is recognized that his consent is a result of his own decision. If the concerned person passes away before his free acquiescence, he will be counted as a disbeliever. The solid reason for the prevention of force, here are the words of Almighty Allah that there is no compulsion in religion. (Al-Muqaddasī, 1987, p. 144)

Therefore, it is perceived no Muslim state, group, or an individual can force a non-Muslim to accept Islam in any case. Muhammad Fathī Uthmān declared it more cogently:

No authority of any sort in the Islamic state may be engaged to force people to accept Islam. The basic task of the Islamic state, in this view, is to observe and avert the powers which may seek to refute the public their right to liberty of faith and copiousness. (Fathī, 1982, p. 91)

The Islamic law protects the religious belief of non-Muslim minorities' same like as the Muslims. A reputed jurist 'Abd al-Wāḥid al-Wāffì commented:

Islam recognized this principle and advised his supporters to deal disbelievers similarly. The Prophet followers adopted this attitude in their conducts because compulsion is not rationally in matter of faith as creed is an emotional measurement unidentified and unrestrained by other people, not outside force can amend or eradicate it. ( Wāffí, 1977, p. 64)

Here, an interesting issue is that the protection of disbeliever's faith and political allies has been also a political strategy of Islam from its foundation. The first written Constitution of the world, known as "Mīthāq-e-Madīnah" is its excellent example. The 25th clause of the Constitution of Madinnah accepts the right of religion and Faith of the Jews of Madīnah, which is the solid proof of the religious liberty in an Islamic state. According to Muhammad Hamīdullah Research: "And the Jews of Ban̄u 'Awf shall be considered as one political community (Ummat) along with the believers-for the Jews their religion, and for the Muslims theirs, be one client or patron" (Hamidullah, 1987, p. 15). On the behalf of this peace charter, "Alī Muhammad Al-Sullābī commented alike:

This charter announced that the right of all kind of freedoms and liberties are secured including freedom of religion and faith or right of peace. The freedom of religion granted under the promise that the Jews have their religion and the Muslim has their religion. (Al-Sullābī, 2008, pp. 2, 213)

Therefore, it may be stated with concuss that freedom of religion is the necessary part of all contemporary Muslim states and societies. The legal discourse of Pakistan is also considered one the best Islamic piece of 
Constitution in Islamic world. Thus, the Constitution of Islamic Republic of Pakistan on the one side represents the Islamic teachings, and on the other side, it shows its commitments to modern rights and liberties with reference to Islam. Hence, according to the prevailing Constitution of the 1973 of the Islamic Republic of Pakistan:

(Freedoms of expression) is with Subject to law, public order and morality. A. Every citizen shall have the right to profess, practice and propagate his religion, B. Every religious denomination and every section thereof have the right to establish, maintain and manage its religious institutions. (The Constitution of the Islamic Republic of Pakistan, 1973, p. 12)

It is a pleasant and undeniable truth that the Constitution of Pakistan has a soft corner towards minorities' rights and liberties. It provides religious freedom and many other civil liberties and fundamental rights to the minorities of Pakistan. Therefore, it is perceived from the above discussion that Islamic society believes on pluralism and diversity by nature and by legality both. The foremost example of this society is the first Islamic state of Madīnah, which was established by the Holy Prophet Muhammad âd and and groomed it by the righteous caliphates. For that purpose, the Prophet of Islam did peace agreement with other faiths and communities and succeeded to establish a model peaceful and diverse society in a most violent and aggressive society of the history. If the society and state of the Prophet allugate has become Islamic and plural, then every kind of our societies can become diverse. It was an exemplary society in all over the world for all humanity where every faith and community was free, happy, and bound to his center of Madīnah, the Capital Federation. The prophetic strategy of peaceful and diverse society can be experienced and exercised firstly in Muslim world, especially in Pakistan and then can be implemented in all over the globe.

Contrary to this, everybody knows it very well; in these days, the world is suffering due to racial and religious discrimination. Most of the countries disagreed with other generations, communities, and faiths. They do not like other communities and religions, even in America racial and gender crimes are on it's the highest level. The Europe is also not safe today. Our neighbor countries, India and Burma (Myanmar), are considered as hell and a prison for minorities. In this scenario, the Charter of Madīnah can prove a tower of light in darkness of discrimination and injustice for world peace and prosperity. We can use Methāq-e-Madīnah as conflict resolution among different faiths, religions, and communities without any war and weapons. Here, we would to share the work of a British scholar William on Methāq-e-Madīnah. He stated about the charter as:

The Medina Charter serves as an example of finding resolve in a dispute where peace and pluralism were achieved not through military successes or ulterior motives but rather through respect, acceptance, and denunciation of war - aspects that reflect some of the basic tenets of the religion Prophet Muhammad, peace be upon him, was guiding and promoting. (at http://www.fountainmagazine.com/Issue/detail/Medina-Charter-and-Pluralism/5/8/18)

Here, as a point of objection, it is observed that India is considered a so-called biggest democracy of the world and Myanmar supreme leader Aan Song Sochi has received Noble peace price from the Western world. But the situation of Muslims in India and Myanmar are too worst in both countries. It is the biggest threat for human peace and shameful act of the international community, including 67 countries of the Muslim world. The issues of Rohingia Muslims have become the wickedest issues of the contemporary world and United Nations Organization (UNO) has declared it an organized genocide from so-called peaceful Buddhists. Hundreds of Muslims killed and died during migration and thousands were compelled to migrate to other countries because they belong to another religion and community. Therefore, it is recommended and suggested 
on the behalf of this forum that Peace Charter of Madīnah (Methāq-e- Madīnah) should be the integral part of international legislations for protection of minorities of any religion and community by UN or any other autonomous global forum.

\section{Conclusions}

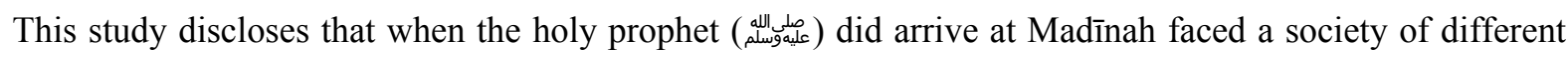
religions and communities amongst of them Muslims, Jews, Christians, and polytheists. To manage these social and religious entities the prophet allugalle made an agreement with all communities and faiths of Madīnah which is called Methāq-e-Madīnah. Methāq-e-Madīnah is considered the most vital document of the prophet's aلd era for promoting peaceful and diverse society. It proved the base of all kinds of peaceful and prosperous and diverse coexistence in the society in a most violent and criminal society. It is also a fact that the Charter of Madinnah can be proved a masterpiece of prophetic political wisdom as well as it was the foundation of all kinds of socio-religious and socio-political tolerance, peaceful coexistence, social and interfaith harmony, and complete justice. It is also perceived from the above study that when all nations, religions, and tribes of

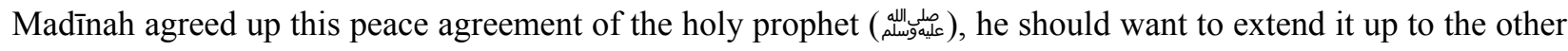
neighbor and nearest tribes of Madīnah to eliminate the bloodshed of centuries and to save the state of Madinnah from Quraysh and warriors attacks. This charter of peace and diversity deals with all kinds of peace and war affairs as well as human rights, social and religious liberties (special freedom of religion), peaceful and diverse social and religious coexistence, and complete social and legal justice of every society even in modern day.

Moreover, this charter provides a base for divers, pluralistic, and peaceful coexistence without any social and religious discrimination in an Islamic state. Subsequently, it is observed without any partiality and discrimination that the Charter of Madīnah was not like a declaration, memorandum, and announcement, but it was a divine Constitution, which was implemented with its real spirit through strong moral and political will and authority. According to the study, it is concluded that this charter has all kinds of effective principles and laws that can save the humanity from every kind of terrorism, injustice, chaos, and uproar even in the contemporary era. So, we try to promote and implement this historical charter of peace and prosperity addition with pluralism and diversity on national and international level. From the above arguments, it can be easily perceived that the Charter of Madīnah has become a universal charter of peaceful and divers coexistence for all humanity. Therefore, it is demanded that the Charter of Madīnah should be part of international legislation regarding minorities' protection for peaceful and diverse society. At least, in Muslim countries, we can practice this charter of peace and diversity for the benefit of the nation.

\section{References}

'Ammārah, M. (1996). Islam and human rights: Prerequisites necessities or mere rights. Rabat: Islamic Economic Social Cooperative Organization.

Abû Dā'ūd, S. A. (2008). Sunan abû Dā'ūd (Sunnah of the Holy Prophet from David). Lahore, Darussalam: Hadīh No.4693.

Ahmad, N. (1983). Naqòsh-e-rasûl (Signs of the Holy Prophet (pbuh)). Lahore: Idārāh Farûgh-e-Urdu.

Al-Muqaddasī, I. Q. (1987). Al-Mughnī Al-Kabīr (A Great Book of Had̄̄th of the Prophet (pbuh)). Egypt: Maktaba al-Qāhira.

Al-Quran, (2004). The Holy Quran. (A. Y. Ali, Trans.). Islamabad: Da'wah Academy, International Islamic University.

Al-Quran, The Holy Quran. (2004). English Translation and Commentary of the Holy Quran by Abdullah Yusuf Ali. Islamabad: Da'wah Academy, International Islamic University.

Al-Sullābī, A. M. (2008). The noble life of the prophet (pbuh). Lahore: Darussalam.

Alvi, K. (2009). Islam ka moasharti nizām (Social System of Islam). Lahore: Al-Faisal. 
Așfahānī, A. N. (1988). Hilyah Al-Aawlīyā (Gold of the Saints). Beirut: Dār al-Kutub al-'Ilmī̄yyāh.

Fathī, U. M. (1982). Ḩuqūq al-Insān Bayna al-Sharī 'ah al-Islāmīyyah wa al-Fikr al-Qānūn̄̄ al-Gharbì (Human Rights in Islamic and Western Legal Thought). Beirut: Dār al-Shurūq.

Hackle, M. H. (1947). Hayāt-o-Muhammad (The Life of Muhammad (pbuh)). Cairo: Nahzah al-Asriyyah.

Hamid, F. A. (2009). The Prophet as a model for universal peace. Insights, 2(2), 1-35.

Hamīdullah, M. (1987). Majmu'ah al-Wathāiq al-Sīyāsīyyah (Political Agreements of the Prophet (pbuh)). Retrieved from http://www.fountainmagazine.com/Issue/detail/Medina-Charter-and-Pluralism/5/8/18.

Hart, M. H. (1992). The 100: A ranking of the most influential persons in history. New York, Kensington Publishing Corporation.

Hmaidullah, M. (1968). The first written Constitution in the World. Retrieved 3/9/17 from https://archive.org/details/thefirstwrittenconstitutionoftheworld/

Mansūpurī, Q. S. (2007). Rahmatullil 'Alamén (Blessing of the Universe). Faisalabad: Maktabah al-Harmain.

Naeem, S. (1998). Muhsin-e-Insāniyyat (Comforter of the Humanity). Lahore: Al-Faisal.

Qāsim, M., \& Krucān, A. (2012). Dialogue in Islam: Quran, Sunnah and History. London: The Dialogue Society.

Quréshī, S. (1998). Foreign politics of the prophet. Delhi: Farīd Books.

Qushairī, M. H. (2007). SahTh Muslim (Authentic Muslim, a Book of Hadith). Lahore, Darussalam: Hadīth No. 64.

Saeed, R. A. (2015). Mīthāq al-Madīnah: Universal Charter of Peace. Research Journal Al-Basìrah, 3(6), 31-58.

The Constitution of the Islamic Republic of Pakistan. (1973). Article No.20, Section (A \& B, Islamabad: Updated Version, 2012). Retrieved from http://www.na.gov.pk/uploads/documents/1333523681_951

Umar̄, Z. (2009). As-Seerah an-Nabwiyyāh as-Sahéhah (Authentic Seerah of the Holy Prophet (pbuh). Riyadh: Darussalam.

Wāffī, A. W. (1977). Baḥūth fì al-Islam wa al-Ijtima (Lectures on Islam and Society). Cairo: Maktabah al-Risālah.

Warrensburg, J. (1998). Religious pluralism and citizenship. The Encounters, 26, 126-147. 